УДК 332.1

\title{
Investment Potential
}

\section{of Structural Modernization of the Krasnoyarsk Economy}

\author{
Nikolai G. Shishatskiy* \\ Krasnoyarsk Department of Institute \\ of Economics and Industrial Engineering \\ of SB RAS
}

50/45 Akademgorodok, Krasnoyarsk, 660036, Russia

Received 14.08.2016, received in revised form 26.09.2016, accepted 27.10.2016

Objective process of integration of Krasnoyarsk into the national and world economy, science, culture have made Krasnoyarsk to compete with other cities for investments, the qualified labor, in granting higher standard of living to the population. To sustain the competition, to the city it is necessary in the right direction to use the internal drivers of economic growth and to be positioned in the best way in the national and world markets, make no mistakes at the choice of perspective specialization and in the strategic plan, correctly predict new needs and technological breaks for the 21st century.

The structural modernization of Krasnoyarsk's economy is necessary for this purpose. It demands carrying out purposeful investment policy the key aspects of which are: the growth stimulation, accumulation and management of all types of investment resources; optimization of structure of use of investments in the priority directions; a solution of the problem of disproportions and ensuring complexity in a development of the city.

Keywords: interregional competition, structural changes in economy, modernization of economy, drivers of economic growth, threat and restriction of economic growth, investment appeal, priorities of investment policy.

DOI: 10.17516/1997-1370-2016-9-11-2792-2802.

Research area: economics.

Krasnoyarsk is a major industrial and cultural center of Eastern Siberia, the capital of Krasnoyarsk Territory as the second-largest subject of Russia.

The position of Krasnoyarsk in the midpoint of this country geographically relatively close to rich and efficient natural resources of Central and Eastern Siberia at the intersection of existing and potential continental railway, automobile, air and naval roads determines development of the city as the biggest industrial as well as transport and logistics center outlines its consolidating role in establishing a single economic and political space of Russia and enables an intensive growth of economy and other urban spheres, basing

(c) Siberian Federal University. All rights reserved

* Corresponding author E-mail address: nik@ksc.krasn.ru 
on the expansion of international economic activity and cooperation.

Due to the advantages of its economic and geographical position and also as a result of effective cooperation of the urban community under the priority strategic focuses, Krasnoyarsk is increasingly enhancing its demographic, economic, investment and scientific potential and becoming one of the most rapidly growing cities in the country.

As to January 1, 2016 the city's population was 1069,4 thousand people (ranked 12 $2^{\text {th }}$ among the major cities in Russia). In terms of population growth pace in 2010 - 2015 Krasnoyarsk took the $2^{\text {nd }}$ place among the Russian cities-millionaire and $4^{\text {th }}$ place among the cities of more than 500000 inhabitants.

Among the major Siberian cities with populations more than 500 thousands of people Krasnoyarsk holds a leading position: in terms of retail turnover per capita, on average monthly salary and on residential houses commissioning per capita.

In 2014 the share of Krasnoyarsk in houses commissioning in the Krasnoyarsk Territory was $51,2 \%$, in retail trade turnover $-58,2 \%$, in public service delivery $-66,0 \%$ It also contains more than $40 \%$ of social facilities (i.e. educational, medical, cultural and art) of the region.

In 2000s Krasnoyarsk implemented a large-scale program concerning the shifting from de-industrialization policy peculiar to the economic recession of 1990 s, to the strategy of renewed growth, increase in gross municipal product, budget capacity and residents' incomes.

The city development kept to several strategic directions and its major results were the following:

1. Significant success of particular economic sectors and branches on national and international markets: a. Strengthening of the city as one of the leading centers for the national and global metal industry.

Most significantly it is achieved by the formation of a large cluster of metallurgical enterprises specializing in aluminum. This cluster is represented by leading companies performing primary processing of aluminum and, partially, providing products of higher degrees: "RUSAL Krasnoyarsk Aluminum Smelter", JSC (production of primary aluminum, aluminum alloys and high-purified aluminum); "Krasnoyarsk Metallurgical Plant”, LLC (primary aluminum and alloys re-processing into ingots, extrusions, bars, pipes, forgings and rolled aluminum production); "SIALMET", Group of Companies (aluminum systems for architecture, building form, building constructions, sheet metal products, products for water- and railway transport); "K\&K”, LLC (alloy wheel rims).

The leading enterprise in Russia and in the whole world is "The Gulidov Krasnoyarsk Non-Ferrous Metals Plant", JSC "Krastsvetmet" which makes refining of all the metals, jewelries and engineering products from precious metals. Among its customers, there are major Russian companies extracting non-ferrous metals, i.e. "Mining and Metallurgical Company "Norilsk Nickel", PJSC, "Polyus", PJSC, "Polymetal International plc", LLC and foreign partners form the UK, Czech Republic, USA, Australia, Switzerland and Italy.

The cluster also includes "Germanium", JSC, the only enterprise in Russia that has a full cycle of processing, wide range of products and large production capacity.

b. Development of the transport hub as one of the most perspective multi-modal transport hubs of federal importance.

The core of Krasnoyarsk transport hub are Yemelyanovo airport which is reckoned among top-10 largest Russian freight hubs (25 thousand 
tons in 2014) and holds $14^{\text {th }}$ place in terms of passenger traffic ( 2 million of passengers in 2014), and the railway hub consisting of 8 freight and passenger stations with the freight turnover of 11,1 million tons per year (in 2012) and passenger turnover of 4,4 million persons (including 720000 persons for long-hauls and 3680 thousand persons for commuter ways).

A significant contribution to the urban transport hub development is made by the river waterfront complex which at the present time work at only $10-20 \%$ of its capacity -400 thousand passengers in 2014 (1, 8 million passengers in 1990) and 1, 5 million tons of freight in 2014 (20 million tons in 1990).

c. Major logistics complexes established and performing on the Krasnoyarks territory. The development of integrated logistics in Krasnoyarsk is caused by the arrival of large federal operators and trade companies. Recently the Krasnoyarsk market has met numerous major logistics enterprises ("Gruzovozoff”, "Warehouse Logistics Center", "Rail Continent", "STK Logistics - Krasnoyarsk", "SibTrans - Service", "SIBCONT - Krasnoyarsk" and etc.) and there has been an increase in the tonnage capacity of transport and logistics market.

At the same time, the development of Krasnoyarsk warehouse system has been characterized by the dominance of middle and lower class warehouses oriented on the extension of retail network. Such situation is caused by a predominant enhancement of forwarding services on the logistics market. As for integrated logistics services in 3-PL and 4-PL providers sectors, so they are largely absent on the Krasnoyarsk market excluding such single companies as STK "Lenkom" and "Terminal".

d. Development of the information and communication cluster. There are a number of successfully operating large companies of ICT in Krasnoyarsk and its new town Zheleznogorsk :
- "Research and Production Company "Radiosvyaz", JSC, is the leading Russian enterprise in the sphere of development and production of satellite and tropospheric communication earth stations, radionavigation complexes for the Ministry of Defense of the Russian Federation, Federal Security Service and Federal Protection Service of the Russian Federation and for other government orders.

- "Central Design Bureau "Geophisics" of the Federal Space Agency develops and produces powerful high-frequency semi-conducting radio devices, automation and measuring equipment and geophysical instruments;

- "Academician M.F. Reshetnev Information Satellite Systems", JSC (Zheleznogorsk) produces 2/3 of all the satellites included in the Russian orbital network.

The leading Russian universities are engaged in training of specialists for the information and communication complex: Siberian Federal University (ranked $6^{\text {th }}$ in terms of the graduateon-demand rate and $15^{\text {th }}$ in terms of R\&D activity [Reiting luchshihh vuzov Rossii agentstva «Ekspert RA» po itogam 2014/2015 uchebnogo goda]) and Siberian State Aerospace University (SibSAU) (ranked $60^{\text {th }}$ in terms of the graduateon-demand rate and $65^{\text {th }}$ in terms of R\&D activity [Reiting luchshihh vuzov Rossii agentstva «Ekspert RA» po itogam 2014/2015 uchebnogo goda]).

e. Construction of the modern cluster of complex business and financial services (bank services, PR, advertisement, insurance, legal services and etc.). The banking network in the city is represented by 71 banks, 299 branches and 1607 ATMs. There predominantly are territorial branches of the major Russian banks registered in Moscow. Four banks are regional with their headquarters located in Krasnoyarsk: the leading one is "Kedr", Commercial Bank, which takes $40^{\text {th }}$ position among the Russian 
regional banks and $3^{\text {rd }}$ position in the Siberian Federal District in terms of the size of its assets $(29,5$ billion rubles as to January 1, 2015) [Reiting krupneishikh regional'nikh bankov kompanii «AnalyticResearchGroup»].

f. In Krasnoyarsk, a significant rise has been recorded in the construction sector, building material industry and real estate operations. A differentiated and quite extensive agglomeration zone formed around the city now includes not only residential, but also commercial real estate.

g. The modern food industry also develops in the city: in the eastern region Krasnoyarsk is one of the major production centers for confectionary, milk and meat products.

2. Development of the second largest (after Novosibirsk) and one of the most significant in the Siberian Federal District consumer markets supported by:

- Automobilization, i.e. a sharp climb in the number of cars in personal and commercial sectors of the urban economy (the number of cars per 1000 inhabitants). In 2015 Krasnoyarsk reached one of the highest levels of automobilization among the Russian cities -390 cars per 1000 inhabitants. By 2030 this indicator is expected to rise up to 600 cars per 1000 inhabitants, and its total number up to 800 thousands.

- Growth in trade volumes and expansion of the modern trade forms. At the present time there has been formed almost the whole range of modern trade forms. Krasnoyarsk contains 13 large shop centers functioning on a total area about 450 thousand sq. $\mathrm{m}$ of GLA. In terms of GLA commercial space availability (415 thousand sq. m per 1000 inhabitants as to January 1, 2016) Krasnoyarsk holds 8th position among cities with a million-plus population (followed by Kazan, Novosibisrk, Omsk, Voronezh, Volgograd, Ufa and Perm) [Obzor rynka torgovoi nedvizhimosti kompanii Colliers International];
As to January 1, 2015 the urban retail chain stores was represented by 88 out of 450 (18\%) international brands existing in Russia [Reiting gorodov Rossii 2014 po prisutstviiu mezhdunarodnikh brendov]. According to this indicator, Krasnoyarsk takes 12th place outpacing Omsk, Chelyabinsk, Voronezh, Perm and Volgograd;

- Diversification and complication of the service market. Leisure activity has become an essential economic sphere of the city and, at the same time, the most important area of consumer expenditures.

- IT development and expansion of information and communication technologies, i.e. the entry of the last into daily life of the citizens (the level of Internet and cells use, e-payment system and remote services access system application, and etc.);

- Free (public) and commercial services in the spheres of health, education, recreation, sport and physical training.

3. Streamlining of the urban engineering infrastructures:

a. In the sphere of energetic (construction and re-construction of the heat supply systems, new power generating unit launch at the Krasnoyarsk CHP-3, extensive investment program of Federal Grid Company of the United Energy System.

b. In the sphere of transport (transport access to the city, modernization of the major urban roads, bridges, commissioning of the 4th municipal bridge over the Yenisei and etc.);

c. In the systems of water-supply and water disposal, sanitary purification and waste control.

4. Formation of a new sector for the budget revenues including through the involvement of large taxpayers (RusHydro, Siberian Coal Energy Company (SUEK), PJSC ROSSETI, JSC VANKORNEFT, Taymir Fuel Company and etc.) 
Table 1. Largest taxpayers of Krasnoyarsk

\begin{tabular}{|c|c|c|c|c|c|}
\hline Place & Company & Field & $\begin{array}{l}\text { Turnover in } \\
\text { billion RUB }\end{array}$ & $\begin{array}{l}\text { Net profit in } \\
\text { billion RUB }\end{array}$ & $\begin{array}{c}\text { Profitability, } \\
\%\end{array}$ \\
\hline 8 & RusHydro & $\begin{array}{l}\text { Production of electricity by } \\
\text { hydropower plants }\end{array}$ & 108.5 & 30.7 & 28.33 \\
\hline 12 & Krastsvetmet & Precious metals & 70.3 & 2.4 & 3.35 \\
\hline 20 & IDGS of Siberia & Power engineering & 57.4 & 0.1 & 0.19 \\
\hline 23 & $\begin{array}{l}\text { RUSAL - Krasnoyarsk } \\
\text { Aluminum Smelter }\end{array}$ & Non-ferrous metals & 43.8 & -0.0 & 0.00 \\
\hline 42 & Komandor & $\begin{array}{l}\text { Trade (a network of } \\
\text { supermarkets, furniture shops, } \\
\text { etc.) }\end{array}$ & 25.2 & 0.4 & 1.60 \\
\hline 60 & SUEK-Krasnoyarsk & Coal production & 16.7 & 3.1 & 18.77 \\
\hline 63 & Eniseiskaya TGK (TGK-13) & Power engineering & 16.2 & 2.2 & 13.32 \\
\hline 64 & $\begin{array}{l}\text { RN-Krasnoyarsknefteprodukt } \\
\text { (Rosneft company) }\end{array}$ & Sale of oil products & 15.7 & -0.3 & -1.76 \\
\hline 69 & Krasnoyarsknefteprodukt & Sale of oil products & 14.5 & 0.3 & 2.07 \\
\hline 83 & $\begin{array}{l}\text { Krasnoyarsk metallurgical } \\
\text { plant }\end{array}$ & Non-ferrous metallurgy & 11.8 & 0.6 & 5.48 \\
\hline 90 & \begin{tabular}{|l|} 
Krasnoyarsk DH \\
Transportation Company
\end{tabular} & Power engineering & 10.9 & -0.5 & -4.13 \\
\hline 96 & Taymyr Fuel Company & $\begin{array}{l}\text { Transportation and logistics } \\
\text { (transportation of oil products) }\end{array}$ & 10.1 & -0.4 & -4.14 \\
\hline
\end{tabular}

The ranking of the largest companies in Siberia in terms of turnover in 2014 includes 56 Krasnoyarsk companies, 12 of them are in the top 100 of the best companies.

(Table 1). That has provided a significant gain in budgetary revenues of the city.

5. Implementation of the "second capital of Siberia" strategy and large flagship projects of the federal and cross-regional levels.

Krasnoyarsk includes the operating Office of the Belorussia Embassy, Honorary Consulate of Slovakia, Central Siberian Chamber of Commerce and Industry in Russia and a number of other international and federal organizations. Krasnoyarsk is a ground for one of the main Russian event - Krasnoyarsk International Economic Forum - and also a participant and initiator of numerous cultural, sport and education projects, such as: the Krasnoyarsk International Festival of Chamber Music "Siberia - Europe", Golden Grand Prix Ivan Yarigin, Open FestivalCompetition of Snow and Ice Sculptures "Magic
Ice of Siberia". The city holds international seminars and forums of the highest level. To the most prominent events being highly important for the country's image, one can add the decision to keep XXIX International Winter Universide 2019 in Krasnoyarsk.

As the significant result of transformations, there has been a change in the urban community, in its values and personal strategies of the residents. In particular, the education has gained a mass-scale characteristic. There has been re-comprehension of the leisure time spent not outside, but inside the city, which set new requirements for the urban environment.

The city has changed as a platform for the leisure time: new requirements for the spatial and landscape area, for the quality of architectural decisions have been established; there also has 


\begin{tabular}{|c|c|c|}
\hline $\begin{array}{l}\text { Outrunning growth of population } \\
\qquad(1989=100 \%)\end{array}$ & $\begin{array}{l}\text { INDUSTRIAL CENTRE } \\
250 \text { major industrial centres of Russia- } \\
2013 \text { (Urbanika) }\end{array}$ & $\begin{array}{l}41 \text { place in Russia } \\
\text { (13 among million- } \\
\text { plus cities) }\end{array}$ \\
\hline & POSSIBILITIES FOR BUSINESS & $19^{\text {th }}$ place \\
\hline & $\begin{array}{l}30 \text { best cities for business }-2013 \\
\text { (Forbes) }\end{array}$ & $\begin{array}{l}\left(1^{\text {st }} \text { place in }\right. \\
\text { Siberia })\end{array}$ \\
\hline & $\begin{array}{l}\text { INNOVATION POTENTIAL LEVEL } \\
\text { Innovation Cities Global Index-2015 } \\
\text { (2thinknow) }\end{array}$ & $\begin{array}{l}7^{\text {th }} \text { place among } \\
\text { Russian cities }(2 \text { in } \\
\text { Siberia) and } 280^{\text {th }} \\
\text { in World cities }\end{array}$ \\
\hline 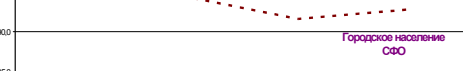 & URBAN ENVIRONMENT QUALITY & $16^{\text {th }}$ place in Russia \\
\hline $\begin{array}{l}\text { Krasnoyarsk is among } 12 \text { major } \\
\text { cities of the Russian Federation }\end{array}$ & $\begin{array}{l}\text { city for living (settlement) according to } \\
\text { the results of cities' activity for } 2013 \\
\text { (Russian Union of Engineers) }\end{array}$ & \\
\hline $\begin{array}{l}\text { and } 3 \text { leading cities in SFD and } \\
\text { is characterized by outrunning } \\
\text { population growth rates. }\end{array}$ & $\begin{array}{l}\text { FINANCIAL STABILITY } \\
\text { International Rating Agency } \\
\text { (FitchRating (2014) }\end{array}$ & $\begin{array}{l}\text { Long-term rating in } \\
\text { international and } \\
\text { national currency } \\
\text { BB, short-term in } \\
\text { national currency B, } \\
\text { rating in national } \\
\text { scale AA-(rus) }\end{array}$ \\
\hline
\end{tabular}

Fig. 1. Krasnoyarsk - 2015: starting positions

been a fundamental reconstruction in the functions of public places - so called "third places" chain (i.e. places considered as being on the border between personal and pubic space), used both for recreation and business (i.e. equipped with free Wi-Fi access, open grounds, cafes, creative centers and etc.), has been built.

There also have been drastic changes in the citizens' preferences on the labor market. Those staff position and strategies have appeared to be the most requested, which provide the greatest freedom for a person and their economic and social sustainability. Consequently, the urban space of Krasnoyarsk has been changed for these values (the city of innovations, partnership and cooperation).

The results of such city development in the mentioned spheres are: proportionally higher population growth; strengthening of the role of industrial center; business environment improvement; growth of investment potential; urban environment improvement; contribution to greater financial stability (Fig. 1).

Due to high indicators of the socio-economic development Krasnoyarsk is often mentioned in the leading Russian and international ratings.

In the General Rating of the Russian City Appeal (Russian Union of Engineers, 2015) Krasnoyarsk holds $16^{\text {th }}$ position (out of 165 , followed by such developed cities as Ufa, Omsk, Nizhnii Novgorod, Voronezh, Volgograd, Perm, Chelyabonsk and Samara) and the $2^{\text {nd }}$ place among the cities of Siberian Federal District (after Novosibirsk) [Generalnii reiting privlekatelnosti gorodskoi sredy prozhivaniia (obitaniia) po itogam deiatelnosti gorodov za 2013 god].

According to the "Russian Reporter" magazine, during the last five years Krasnoyarsk has clearly been ranked in the top-10 perspective Russian cities.

In 2014 Fitch Ratings, the international rating agency, once again proved the long-term 
ratings of Krasnoyarsk in foreign and national currency. The city's economy was recognized as strong and sustainable.

Regarding 2thinknow: innovation Cities Golden Index 2015 (consisted of 162 indicators) the innovative capacity of Krasnoyarsk was highly estimated - it took the $7^{\text {th }}$ place among the Russian cities and $280^{\text {th }}$ in the whole world [1].

As it has been assessed by McKinsey Global Institute, the international consulting company, Krasnoyarsk is one of the five Russian cities which by 2025 will have been included in the list of 600 leading cities of the worlds and become the sources of highest economic and demographic growth containing $60 \%$ of the world's wealth.

Thus, Krasnoyarsk possesses a good potential (economic, innovative, territorial and social) for the further growth and has every reason to develop intensively and multi-functionally. Alongside, the effective development might be impeded by the problems and restrictions in the sphere of economy, natural and climatic conditions, ecology and social sector.

Among economic problems the following stand out most acutely:

- The loss of leading positions in the technical and industrial development: the share of manufacturing is less than $10 \%$ in the backdrop of a significant share of service sectors;

- A dominant role of metallurgy in the processing industry that increases dependence of the urban economy on the global market environment and, particularly, on the prices of metals;

- The low level of economic diversification, where the biggest part of involved people is in the sectors of public and social services characterized by least contribution to the gross municipal product of the city;

- The high level of physical and moral depreciation of equipment and lack of company's own budget for it upgrade and modernization;
- Low (in comparison with developed countries) workforce productivity over the whole range of economic sectors and industries;

- Disproportions between the labor market needs and system of training specialist personnel.

It should also be mentioned about a low investment attractiveness of the city and a high level of investment risks in comparison with neighbor regions, as well as about insufficiently attractive conditions for small and medium enterprises development.

An important factor which constrains the development of Krasnoyarsk is it territorial remoteness from the major market places and business centers of the Russian Federation. The city is located in ultra-continental geographical zone characterized by it maximum remoteness (2000 and more $\mathrm{km}$ ) from the sea ports with yearround navigation.

The distance from Krasnoyarsk to the nearest Russian warm-water seaports is: to Novorossiisk (4916 km), to Vostochniy seaport (in Nakhodka) $(4996 \mathrm{~km})$ and to Murmansk $(5360 \mathrm{~km})$.

The territorial remoteness together with insufficiently developed transport infrastructure declines the city's chances to be involved in the external market supply with the products of low added value and high share of transport expenditures in the cost structure; leads to the rise in prices on products imported from other regions and, in general, decreases the mobility of people, goods and business.

Among natural and climatic factors influencing on the city development, the most significant is a severe climate. It makes Krasnoyarsk unappealing for work and living and also limits the list of economic activities which can be effectively implemented here.

A contrary ecological situation is another considerable force that restricts Krasnoyarsk's development. A high proportion of ecologically 
harmful and anthropogenically dangerous manufactures and objects located in the close proximity to residential areas results in that during many years Krasnoyarsk has been in the list of Russian cities with the most polluted air. According to the statistics of environmental and sanitary services, the water in the city's rivers and in its countryside is below drinking water standards. Yenisei is polluted with radioactive wastes made by Krasnoyarsk Mining and Chemical Combine. What makes the situation worse is that a part of production industries in Krasnoyarsk do not include sanitary protection zones and do not meet the current requirements for the environmental protection.

Geopolitical and resource abilities of Krasnoyarsk allow him to achieve, in the near future till $2030-2040$, a position in the top-5 leading cities of the Russian Federation. It requires reaching a long-term sustainable maintenance of the GMP growth within $5-7 \%$ a year. This automatically means that a wager for the economic development of the city cannot be made on traditional industry and mature markets. The economic structure must introduce new branches which grow at the pace of more than $15-20 \%$ per year and able to become an accelerating driver for other industries and sectors.

It's worth noting that the sphere of construction and the real estate market cannot be considered as such drivers, since their growth not based on the growth of other economic sectors will simply pump up a "bubble" of unreasonable projects and ambitions. This role also cannot be played by the sector of public services.

The intensification in globalization processes accompanied by an active removing of capital and knowledge intensive productions by western companies to the countries of Asia and Eastern Europe offers to Krasnoyarsk a variety of opportunities for the development. First and foremost, the city can have on its territory advanced manufactures and production processes introduced by foreign companies. It's convenient geographical position - in the very meddle between Russia and Asia - allows taking a leading position in maintaining integration of the Russian economy into the world's one through sourcing and Asian developing markets access. In this, the growth of global marketability of the city economy endangers possible displacement of the Russian companies from not only international, but also domestic markets.

Strengthening the role of innovation and human capital gives an opportunity to build an innovative economy, but at the same time possesses a risk of increasing technological gap. The developed research and education complex, hi-tech and innovative enterprises and also a high proportion of young population will attract talented people: this is important for the construction of innovative economy with high added value. The main obstacle there can be the absence of infrastructure which allows commercializing scientific researches, lack of needs for innovations form the business part and unattractive environment for the HR practices. The absence of due attention towards these problems increases the risk of technological gap as well as the risk of high-calibre staff departure.

A necessity to attract new residents in the city, to finance the federal center and to get private investors determines a sharp competition between the Russian regions. As a rule, those regions which clearly understand their strategic priorities in the economy and social sphere and implement adopted programs of long-term development, cooperate with the mentioned target groups in a more efficient way and, thus, develop at a better pace.

Today one can speak about this competition in many directions. Thus, Krasnoyarsk is struggling for the leadership in Siberia with Novosibirsk, for the leadership in Eastern Siberia and for the influence on Far East regions - with Irkutsk. 
Table 2. Strategic projects and programmes: assessment of the investment amount up to 2030

\begin{tabular}{|l|c|}
\hline \multicolumn{1}{|c|}{ Field } & $\begin{array}{c}\text { Amount of investments } \\
\text { in billion RUB }\end{array}$ \\
\hline 1. Development of competitive high-tech clusters & $236-324$ \\
\hline 2. To assign the status on interregional centre to the city, including: & 520 \\
\hline - Construction of Krasnoyarsk-City business centre & 80 \\
\hline $\begin{array}{l}\text { - Development and increasing the capacity of the transportation hub (Harbour-type } \\
\text { Special Economic Zone Emelyanovo) }\end{array}$ & 40 \\
\hline $\begin{array}{l}\text { - Development of the city as a global scientific, educational, sportive, recreational and } \\
\text { tourism centre }\end{array}$ & 100 \\
\hline - Efficient development of the agglomeration space Big Krasnoyarsk & 300 \\
\hline $\begin{array}{l}\text { 3. Comprehensive development and landscaping of the territory, development of the } \\
\text { utilities, social and engineering infrastructure of the city }\end{array}$ & 1695 \\
\hline 4. Ecologization of the urban environment, including: & $306-422$ \\
\hline - Gas infrastructure development for heating the city & $200-270$ \\
\hline - Transition of KRAZ to the baked anodes technology & $106-152$ \\
\hline TOTAL & $2757-2961$ \\
\hline
\end{tabular}

Speaking about certain economic directions and industries, it is worth emphasizing, that Krasnoyarsk has to compete with Novosibirsk, Tomsk and Irkutsk in the sphere of R\&D and education; with Yekaterinburg, Omsk, Irkutsk and Novosibirsk - in the sphere of engineering; with Altai and Irkutsk Region - in crustal touristic resources. Apart from this, there are obviously crossed purposes and battle for the key transport hubs with Yekaterinburg, Novosibirsk and Irkutsk; with Kemerovo and Irkutsk Regions and the Republic of Sakha (Yakutia) - for an efficient access to the natural resources.

Comprehension of one's own competitive advantages and strict following the set economic specialization allows the city to become a leader in the competitive battle among the largest cities of this country.

Modernization of Krasnoyarsk's economy which is necessary to provide competitive advantages and high growth of GMP implies significant amounts of investments (approximately, 2,3 - 3,0 billion rubles (at prices of 2014) for the period 2016 - 2030), which considerably (almost in 2,5 - 3,0 times) exceed the current level (Table 2).
An increase of investments in the main capital formation demands for a targeted investment policy, mainly characterized by the following aspects:

- Growth stimulation, accumulation and control over all the types of investment resources;

- Streamlining of the investment pattern applied to priorities;

- Solution for disproportions and integration of the city development;

The successful implementation of such policy would be possible within certain favorable conditions:

- For the Russian economy to resolve the crisis and move on the growth stage;

- Political stability in the country;

- Development of partnerships with the federal authorities, with the Government of the Krasnoyarsk Territory, administrations of other Russian regions, cross-regional organizations (e.g. with the Cross-regional Organization "Siberian Agreement", Association of Siberian and Far East Cities, the Union of Russian Cities, Cross-regional Association of Enterprises Directions and etc.). 


\title{
References
}

Generalnii reiting privlekatelnosti gorodskoi sredy prozhivaniia (obitaniia) po itogam deiatelnosti gorodov za 2013 god [General Rating of Urban Attractiveness: Results of City Activity - 2013]. Available at: http://www.rossijskij-sojuz-inzhenerov.rf/generalnyy-reyting-privlekatelnostigorodskoy-sredy-prozhivaniya-obitaniya-po-itogam-deyatelnosti-go.php

Obzor rynka torgovoi nedvizhimosti kompanii Colliers International [Review on the Real Estate Market by Colliers International]. Available at: http://www.colliers.com/-/media/files/emea/russia/ research/2016/retail_russia_ru.pdf?la=ru-RU

Reiting gorodov Rossii 2014 po prisutstviiu mezhdunarodnikh brendov [Rating of the Russian Cities on International Brands Distribution- 2014]. Available at: http://www.magazinmagazinov.ru/ news/detail.php?ID=13809

Reiting krupneishikh regional'nikh bankov kompanii "AnalyticResearchGroup» [Rating of the Major Regional Banks by “AnalyticResearchGroup”]. Available at: http://www.analyticgroup.ru/ userfiles/file/Region_banks.pdf

Reiting luchshihh vuzov Rossii agentstva «Ekspert RA» po itogam 2014/2015 uchebnogo goda [Best Russian Universities Rating by "Expert RA" - 2014/2015]. Available at: http://raexpert.ru/ rankings/vuz/vuz_2015/

The Innovation Cities ${ }^{\mathrm{TM}}$ Index 2015. Available at: http://www.innovation-cities.com/innovationcities-index-2015-global/9609

\section{Инвестиционный потенциал \\ структурной модернизации \\ экономики Красноярска}

\author{
Н.Г. Шишацкий \\ Красноярский отдел Института экономики \\ и организации промышленного производства СО РАН \\ Россия, 660036, Красноярск, Академгородок, 50/45
}

Объективный процесс интеграции Красноярска в российскую и мировую экономику, науку, культуру вынуждает его конкурировать с другими городами за инвестиции, квалифицированную рабочую силу в предоставлении более высокого уровня жизни населению. Чтобы выдержать конкуренцию, городу необходимо в правильном направлении использовать свои внутренние движущие силы и наилучшим образом позиционироваться на российском и мировом рынках, не ошибиться при выборе перспективной специализации и в стратегическом плане правильно спрогнозировать новые потребности и технологические прорывы в ХХІ веке.

Структурная модернизация экономики Красноярска, необходимая для этой цели, требует проведения целенаправленной инвестиционной политики, ключевыми аспектами которой должны стать: стимулирование роста, аккумуляция и управление всеми видами инвестициионых ресурсов; оптимизация структуры использования инвестиций по приоритетным направлениям; решение проблемы диспропориий и обеспечение комплексности в развитии города. 
Ключевые слова: межрегиональная конкуренция, структурные изменения в экономике, модернизация экономики, драйверы экономического роста, угрозы и ограничения экономического роста, инвестиционная привлекательность, приоритеты инвестиционной политики.

Научная специальность: 08.00.00 - экономические науки. 